\title{
Secular Stagnation and Monetary Policy
}

Lawrence H. Summers

This article is based on the author's Homer Jones Memorial Lecture delivered at the Federal Reserve Bank of St. Louis, April 6, 2016. (JEL E52, E61, H50)

Federal Reserve Bank of St. Louis Review, Second Quarter 2016, 98(2), pp. 93-110.

http://dx.doi.org/10.20955/r.2016.93-110

I

have been engaged in thinking, writing, provoking, and analyzing around the issue of secular stagnation: the issue of protracted sluggish growth, why it seems to be our experience, and what should be done about it. ${ }^{1}$ This paper summarizes my current thinking on those topics and reflects on the important limits monetary policy experiences in dealing with secular stagnation.

The recent sluggish performance of the economy, both in the United States and particularly abroad, motivates this discussion of secular stagnation. Figure 1 depicts successive estimates of potential GDP and the behavior of actual GDP for the United States. While the Congressional Budget Office (CBO) finds a much lower output gap than it did in 2009, that is wholly the result of downward revisions to its estimate of potential GDP (see Figure 2).

Relative to what the CBO thought potential was in 2007, the gap has never been greater. The situation is more negative in Europe, shown in Figure 3, where actual GDP has performed worst and the magnitude of the downward revision has been substantially greater.

The contrast between what happened after the fall of 2008 and what happened after the fall of 1929 was a notable macro-economic achievement. Collapse and catastrophe happened after the fall of 1929 with the Great Depression. There was nothing like the Great Depression after 2008, in part because of aggressive actions of the Federal Reserve and the Treasury. That was a bipartisan achievement. Key steps such as the Troubled Asset Relief Program (TARP) were initiated during the Bush administration. Further steps such as the American Recovery and Reinvestment Act took place during the Obama administration.

But although the recent policy response to the financial crisis far surpassed that which followed the 1929 crash, twelve years after the acute shock the economy is likely to be in a

Lawrence H. Summers is president emeritus and a distinguished professor at Harvard University, and he directs the university's Mossavar-Rahmani Center for Business and Government.

(c) 2016, Federal Reserve Bank of St. Louis. The views expressed in this article are those of the author(s) and do not necessarily reflect the views of the Federal Reserve System, the Board of Governors, or the regional Federal Reserve Banks. Articles may be reprinted, reproduced, published, distributed, displayed, and transmitted in their entirety if copyright notice, author name(s), and full citation are included. Abstracts, synopses, and other derivative works may be made only with prior written permission of the Federal Reserve Bank of St. Louis. 


\section{Figure 1}

\section{Downward Revision in Potential GDP, United States}

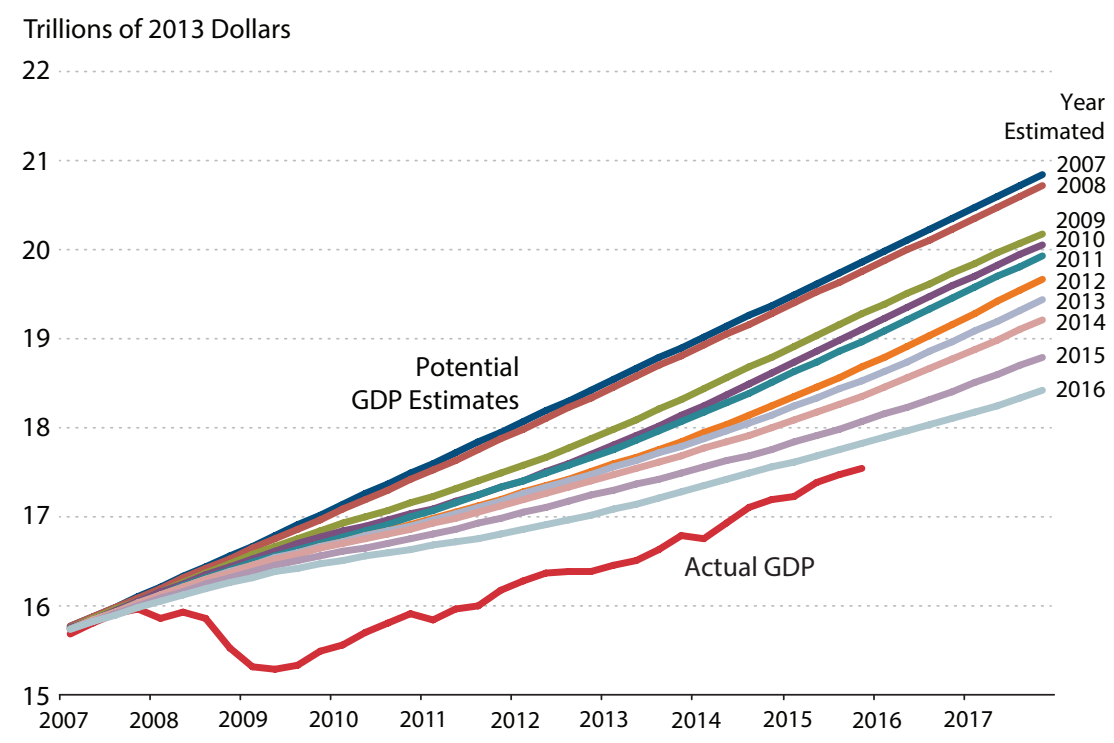

SOURCE: CBO Budget and Economic Outlooks 2007-15; Bureau of Economic Analysis.

\section{Figure 2}

\section{Growth at a Permanently Lower Plateau?}

Nominal GDP Growth, Year-over-Year (percent)

8

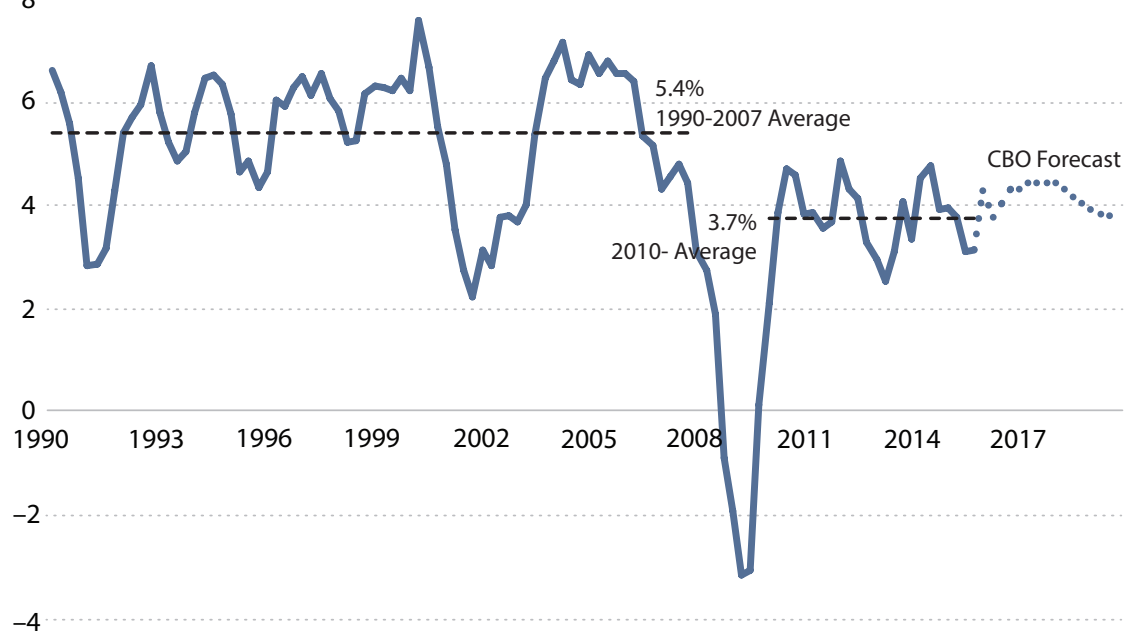

SOURCE: Bureau of Economic Analysis; CBO. 


\section{Figure 3}

\section{Downward Revision in Potential GDP, Eurozone}

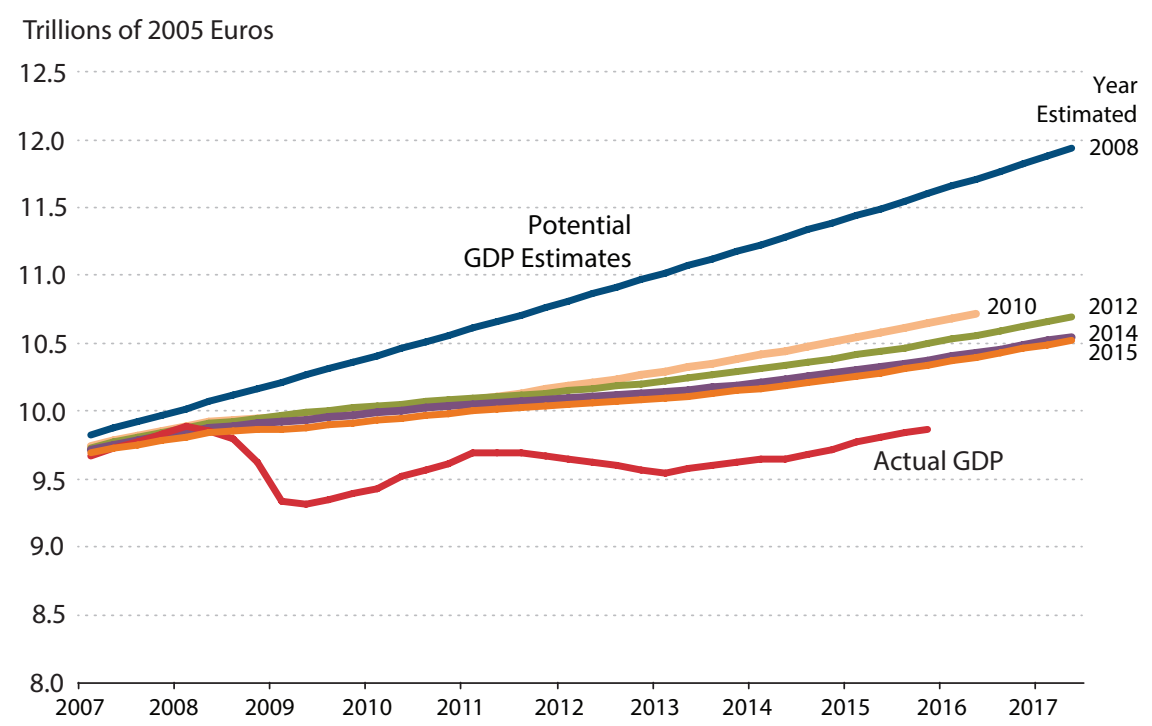

SOURCE: IMF World Economic Outlook Database; Bloomberg.

\section{Figure 4}

\section{Great Recession Very Damaging}

U.S. Real GDP per 18-64-Year-Olds (index: peak $=100$ )

130

Great Depression $(1929=100)$

$120-$ Great Recession $(2007=100)$

- Great Recession: CBO/Census Bureau Forecasts $(2007=100)$

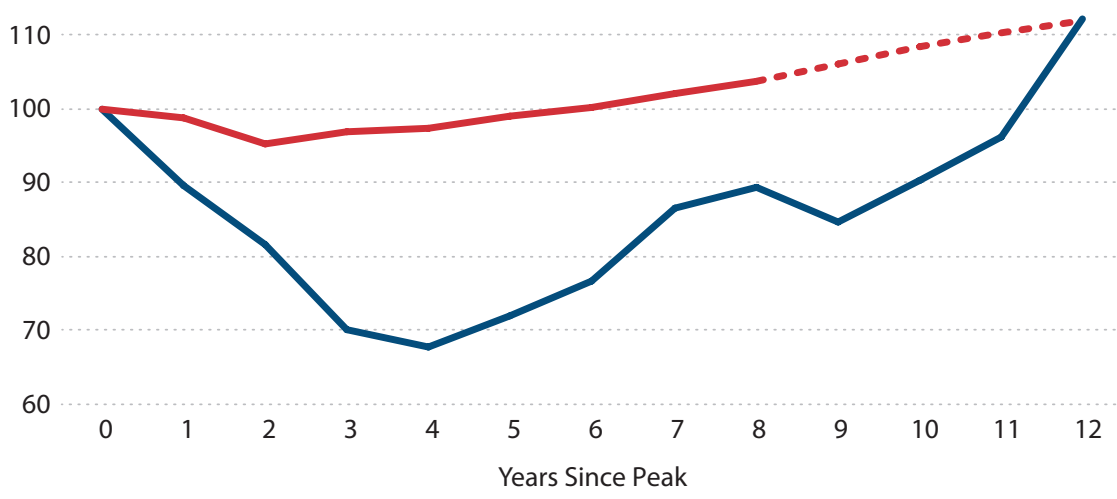

SOURCE: Bureau of Economic Analysis; NBER; CBO; Census. 
similar place. As shown in Figure 4, the current forecast is that GDP per working age American will grow by the same amount from 2007-2019 as it did from 1929-1941. The 1930s are thought of as a lost decade, and the 2010s are an equivalently lost decade. While the economy imploded much more dramatically in the 1930s, it also recovered more dramatically in the 1930s.

At the end of the 1930s, the Harvard economist Alvin Hansen, who was a leading disciple of Keynes, put forward the theory of secular stagnation. Essentially his idea was that, for a variety of reasons including importantly demography and the exhaustion of investment opportunity with the end of the American frontier, there was going to be a tendency in the United States for saving to chronically exceed investment-and therefore for the economy to be short of its full potential a substantial fraction of the time and for there to be at least some deflationary bias in the economy. ${ }^{2}$ Hansen turned out to be completely wrong but completely wrong in a way that suggests that at some future point he could turn out to be right. What actually happened was that the Second World War came along, which brought about a vast increase in demand, and the government became a mass absorber of savings by running large deficits. That propelled the economy very rapidly forward to the point where the unemployment rate went from 11 percent in 1940 to close to 1 percent by $1942 .^{3}$

It was generally believed that, after the Second World War, the economy would return to depression. That turned out to be wrong for several reason. The postwar economy was aided by pent-up demand released by the end of wartime credit controls and rationing; the economy was also aided by a massive government project to build out suburbia. The economy was also importantly aided by an unexpected (and still partially unaccounted for) rise in fertility to nearly four children per woman, which created the Baby Boom. And so the prediction of a chronic excess of saving over investment that Hansen made did not turn out to be hugely relevant in his period. My thesis is that Hansen was a couple of generations too early but that the issues he identified can be a chronic problem for capitalist economies. Moreover, they quite likely are a chronic problem for the economies of the industrialized world today.

Table 1 offers some data on interest rates as inferred from swaps. The numbers are quite small, whether measured by swaps or government bonds. Nominal interest rates are low in the United States and extraordinarily low in Japan and Europe. Inflation rates are expected to be well below 2 percent for the next ten years. Nowhere do markets think that central banks are going to get even very close to their 2 percent inflation targets.

Perhaps most striking is what the expectation is for real interest rates, which can be thought of as the terms for which one can exchange purchasing power this year for purchasing power in the future. The real interest rate in the industrial world is essentially zero. Now, one can

\section{Table 1}

Zero Long-Term Real Rate: Swaps

\begin{tabular}{lrcr} 
& \multicolumn{3}{c}{$\begin{array}{c}10-y e a r \text { interest rates and } \\
\text { expected inflation }\end{array}$} \\
\cline { 2 - 4 } & USA $^{*}$ & Japan & Euro \\
\hline Nominal swap rate & 1.26 & 0.14 & 0.24 \\
\hline - Inflation swaps & 1.51 & 0.21 & 1.08 \\
\hline Real swap rate & -0.25 & -0.07 & -0.83
\end{tabular}

NOTE: *Adjusted for the 0.35 -percentage-point average difference between CPI and the Federal Reserve's preferred PCE inflation rate. SOURCE: Bloomberg. 
argue technical matters involving risk premiums and liquidity premiums and the differences between swaps and government bonds. And while those arguments are interesting, irrespective of any technical adjustments, markets are signaling that for the next 10 years industrial world central banks will uniformly miss their inflation targets despite interest rates far below historical norms.

To preview my argument: If one thought ex ante that there would a big increase in saving and a big reduction in investment propensity, then one would expect that interest rates would fall very dramatically. And so this fall in rates is consistent with a market judgment that the secular stagnation hypothesis is true.

Markets have come to this judgment slowly and painfully. Figure 5 depicts the overnightindexed swap market forwards for short-term interest rates. There is an old joke about the price of shale oil. This joke no longer applies, but the joke is that the price at which it would be profitable to extract shale oil has been constant for 40 years: at the current price of oil plus $\$ 10$. And in the same way, the view of the market has been that normalization is 6 to 9 months away and will take place at a reasonably rapid rate. And that has been the consistent view of the market since 2009. That view has turned out to be very overly optimistic when compared with what happened. And as overly optimistic as the market has been, the Federal Reserve has been even more so. Figure 6 depicts how the Federal Reserve has consistently been above the market, particularly in the past couple of years, with the consistent overoptimism leading to persistent downward revisions in interest rate projections.

In sum, the evidence of unusually stagnant growth is overwhelming, as is the evidence that there is a market expectation of extraordinarily low inflation and extraordinarily low real interest rates going forward. For example, the swap curve in Figure 7 implies that rates are never going much above 2 percent.

This is not all about the financial crisis. This is not all about the current business cycle. There has been a trend-for as long as there have been indexed bonds to use to measure itdownward of real interest rates over the long term.

Figures 8 and 9 depict that one could have used simple extrapolation in 2007 to more or less predict the general area in which real interest rates are today even without the impending crisis. This is not an artifact of near-term developments or of particular things that the Federal Reserve is doing as seen by the so-called five-year five-year rate, which is the market expectation of what the five-year real interest rate will be five years from now. So it is not about anything ephemeral or current; it is essentially the same picture of a very substantial and continuing decline over the longer term.

Capital is mobile around the world, so economic theory predicts the industrial world as a whole would experiencing similar dynamics. And sure enough, the foreign 10 -year yield adjusting for expected inflation exhibits exactly this picture of a sharply and continuing declining real interest rate (Figure 10).

What is the natural way to explain these phenomena? The natural way to explain the phenomena is to imagine that there has been a set of forces that have pushed up the saving propensity and pushed down the investment propensity, and therefore the interest rate that has been necessary to equilibrate them has been under substantial downward pressure and 


\section{Figure 5}

Market Has Been Too Optimistic...

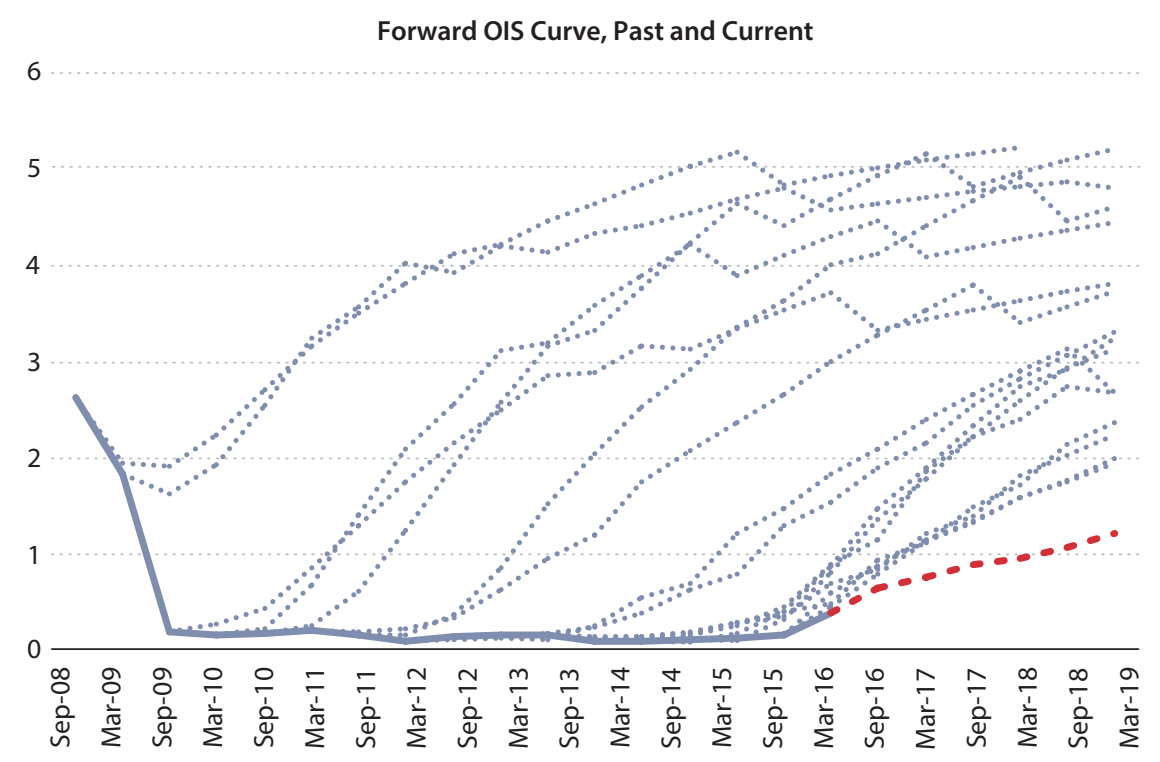

SOURCE: Bloomberg.

\section{Figure 6}

...But Consistently More Pessimistic Than the Fed...

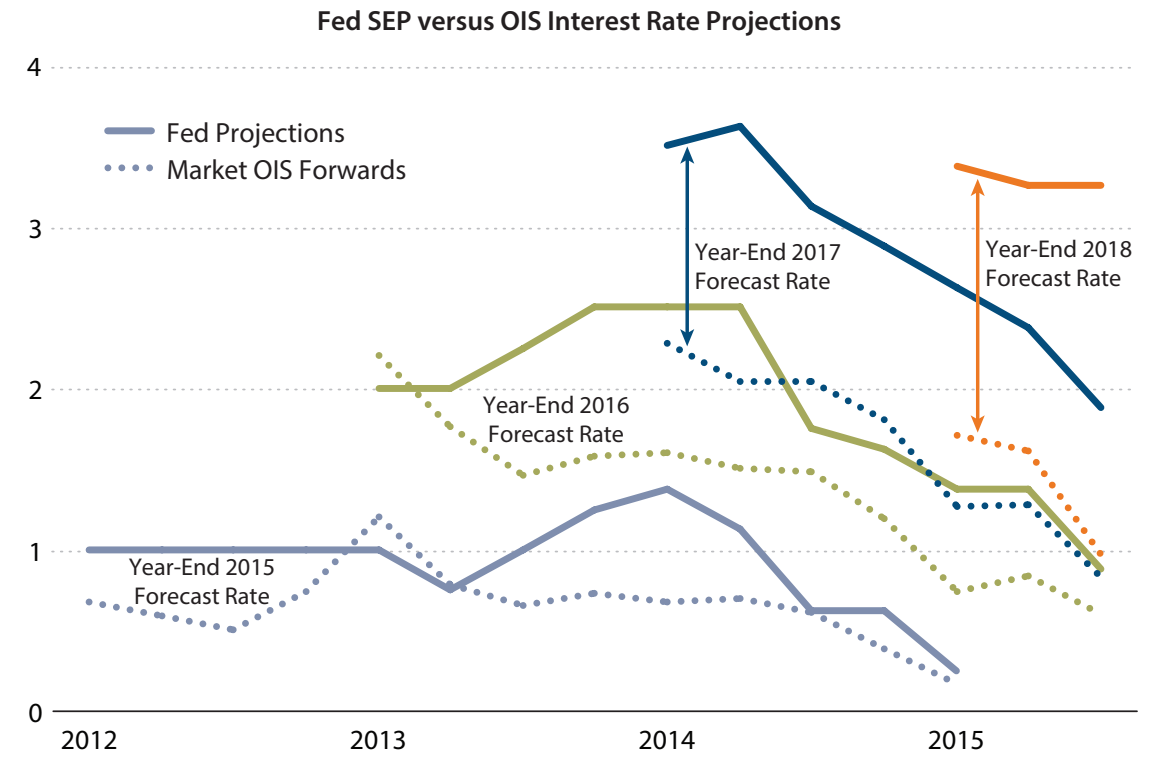

SOURCE: Federal Reserve Summary Economic Projections Fed Funds Median Projection; Bloomberg. 


\section{Figure 7}

\section{...And Is Now Pricing Very Low Rates}

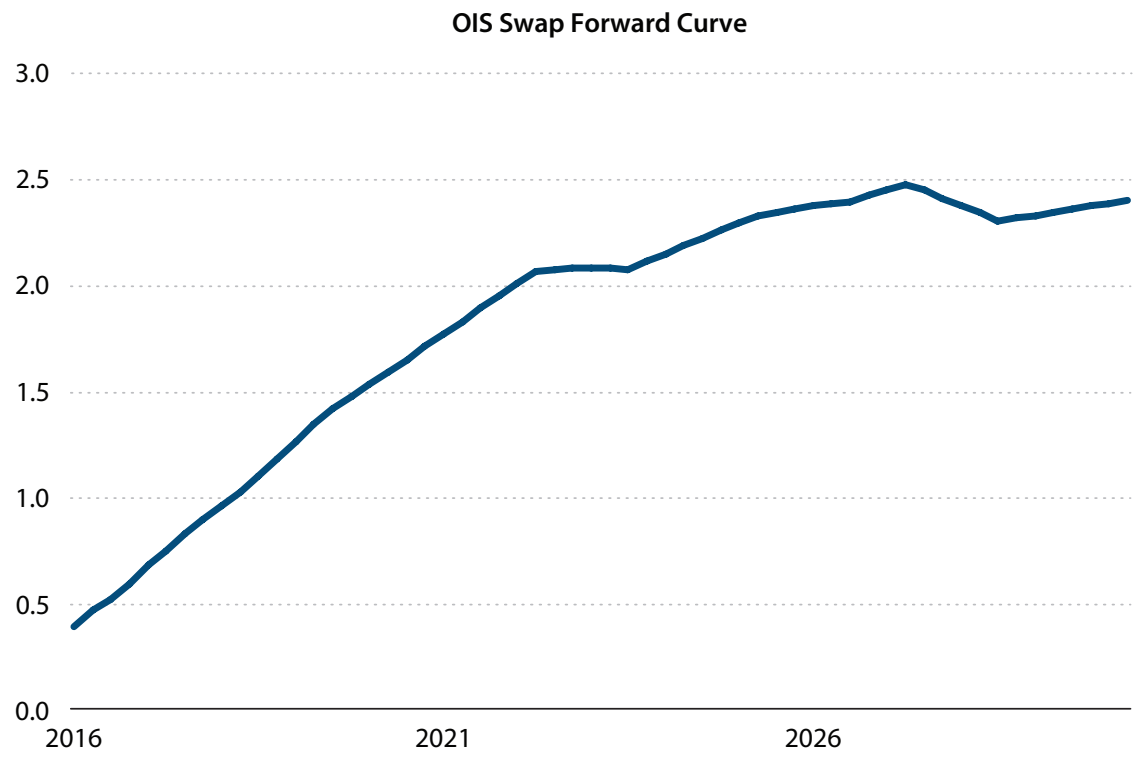

SOURCE: Bloomberg.

Real Rates Have Fallen Steadily...

\section{Figure 8}

\section{U.S. TIPS 10-Year Real Yield}

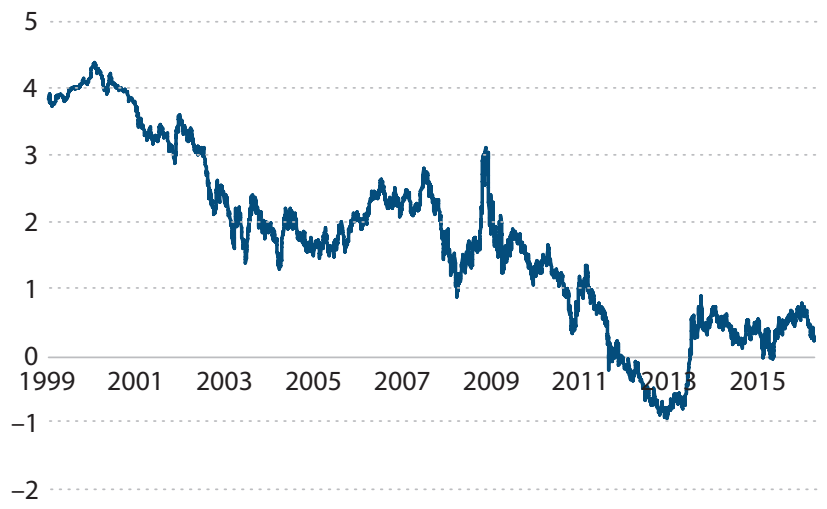

SOURCE: Bloomberg.

\section{Figure 9}

\section{U.S. TIPS 5- to 10-Year Real Yield}

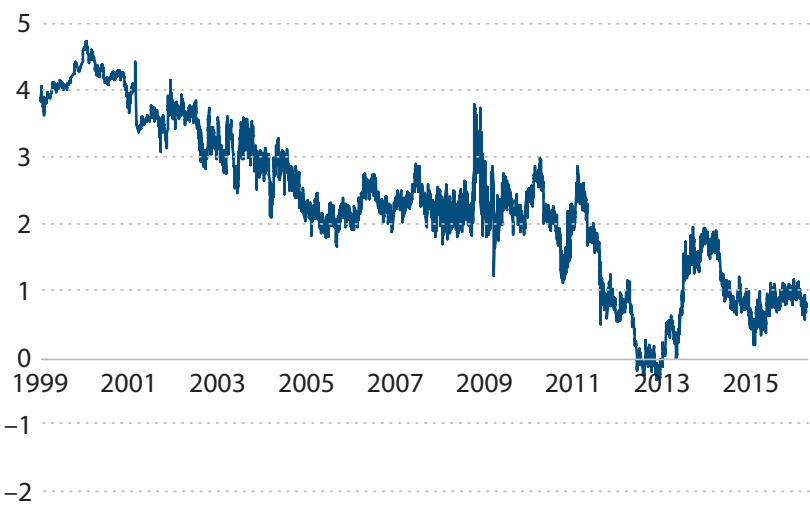

SOURCE: Bloomberg 


\section{Figure 10}

\section{...Along With Rates in the Rest of the World}

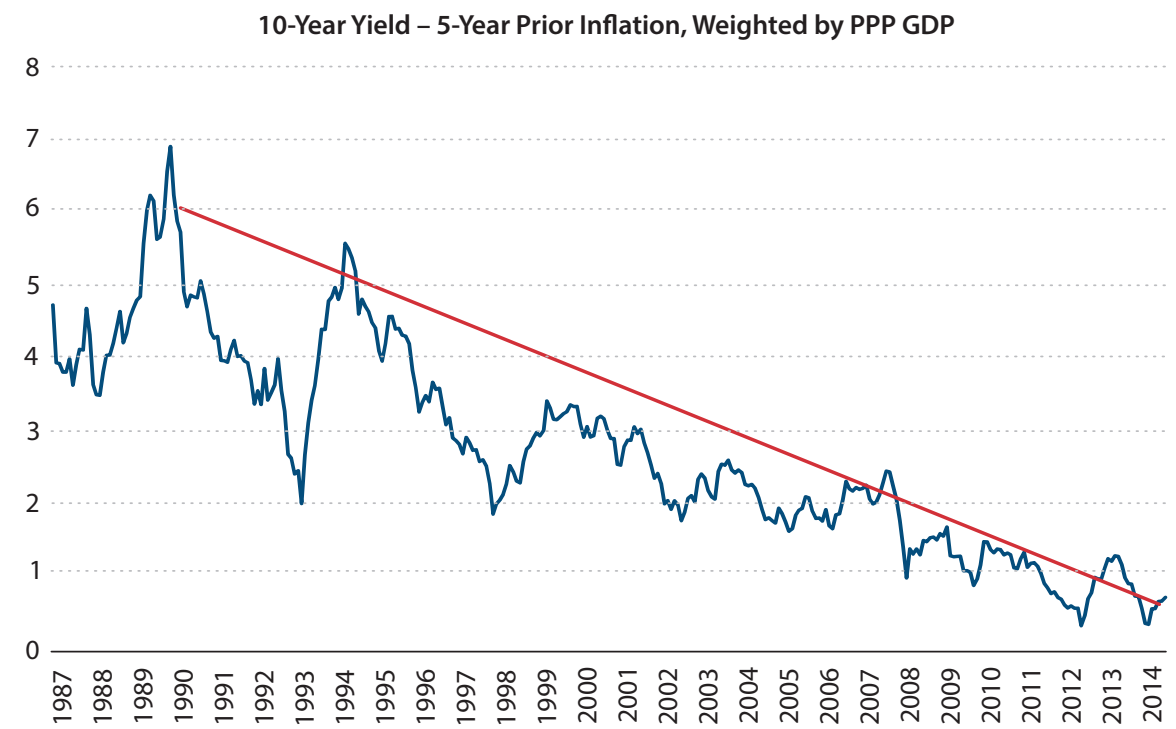

SOURCE: Bloomberg; IMF.

that at some points they have not been equilibrated. And so the mechanism that equilibrated them with excess saving and insufficient demand has been a lower level of income than would otherwise take place. Is that a plausible view? Well, one way to answer the question (although I do not think it is ultimately the most persuasive) is to try to measure what the neutral real interest rate is: more technically, to try to measure what the intercept is in the Taylor rule and thereby answer the question "when the economy is normal, what real interest rate do we observe and has that changed?"

If the economy is strong, the real interest rate would be expected to be above the thencurrent rate. If the economy is slow, we figure the neutral rate is below the then-current real rate. A variety of econometricians have attempted to do this, shown in Figure 11. Most conclude that the current real neutral rate is substantially negative and has been trending somewhat downward over time (Figure 12).

The Fed has noticed and over the past few years has revised downward its estimate of the neutral real rate. But the Fed's adjustments (Figure 13) are much smaller than the trends that the market is seeing as reflected in long-term real rates. And they are pretty small compared with the adjustments that are suggested by the econometric estimates to measure neutral real rates.

So what I have not yet discussed-but which is maybe the most important question for thinking about these issues-is, "What is it that caused saving to rise and investment to decline and therefore to create this downward pressure, this tendency toward stagnation?"

There is actually a plenitude of factors that could bring about this outcome (Figure 14). Increases in the savings propensity might be expected to come from rising inequality and the 


\section{Figure 11}

\section{Empirical Estimates of the Real Natural Rate}

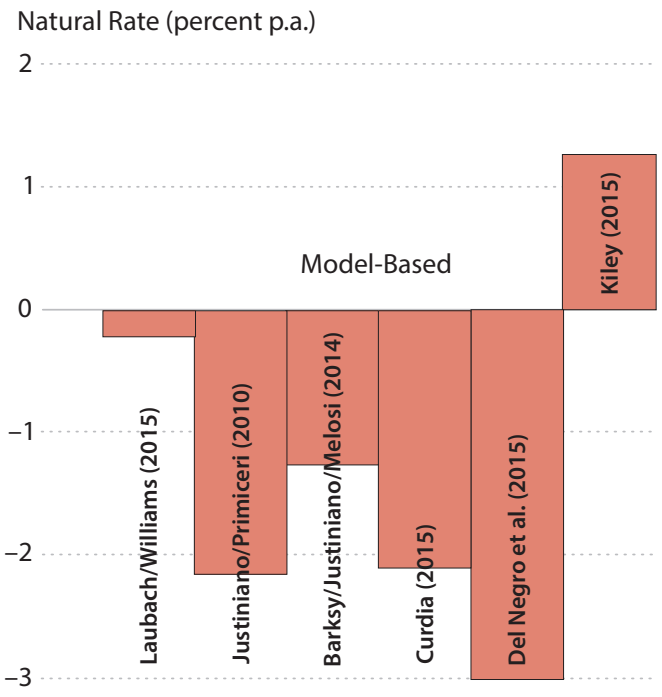

SOURCE: Anna Cieslak discussion of "The Equilibrium Real Funds Rate: Past, Present and Future"; http://www.brookings.edu/ /media/Events/2015/10/interest-rates/Disc_HHHW_02.pdf?la=en.

\section{Figure 12}

\section{Decline in Real Equilibrium Rate}

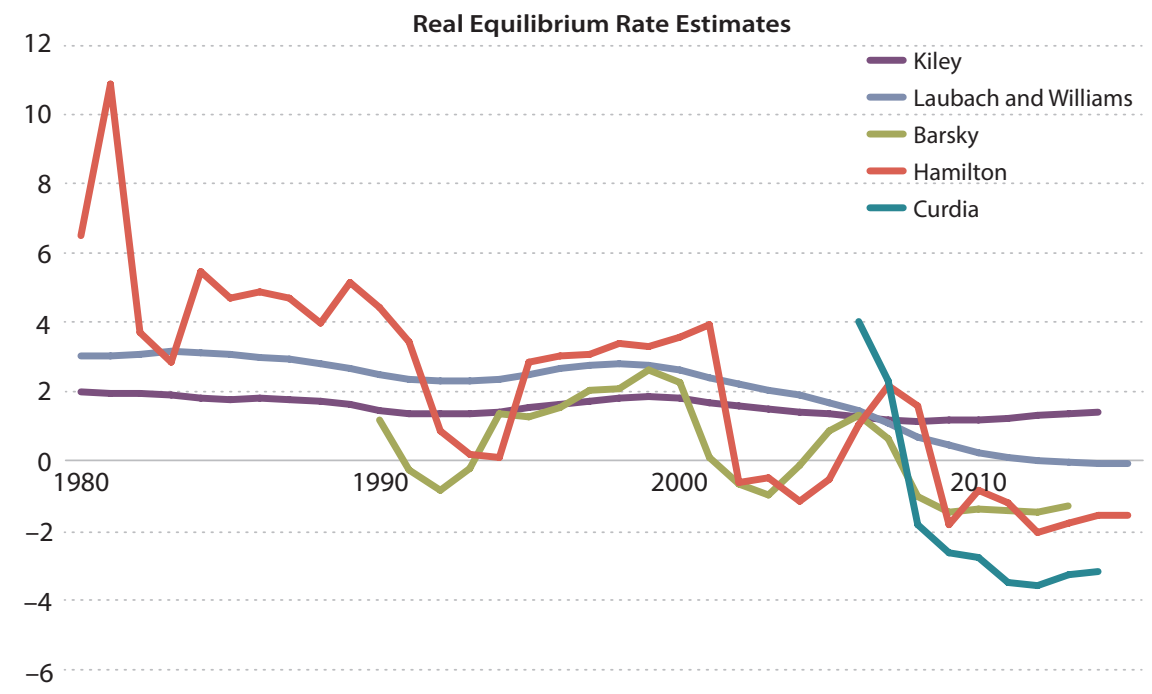

SOURCE: Michael Kiley "What Can the Data Tell Us About The Equilibrium Real Interest Rate," Laubach \& Williams "Measuring The Natural Rate Of Interest Redux," Hamilton et al. "The Equilibrium Real Funds Rate," Vasco Curdia "Why So Slow? A Gradual Return For Interest Rates," Barsky et al. "The Natural Rate \& Its Usefulness for Monetary Policy Making." 


\section{Figure 13}

\section{Fed Estimates of Neutral Rate Have Fallen}

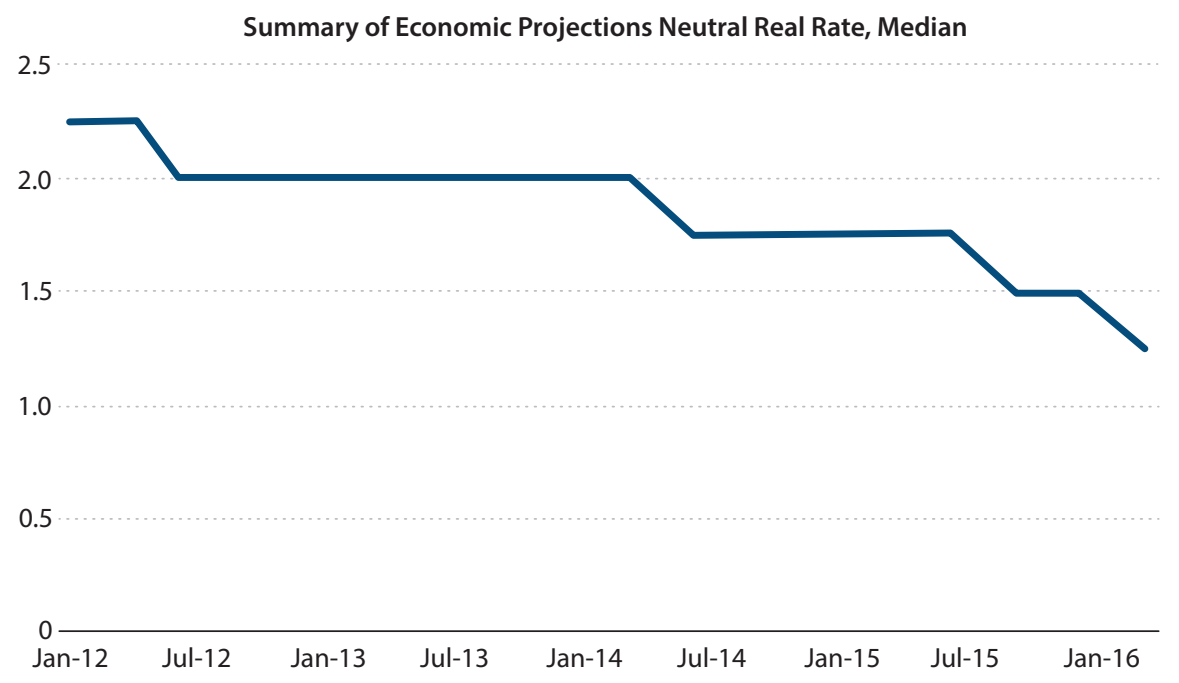

SOURCE: Federal Reserve Quarterly Summary of Economic Projections, 2012 to the present.

observation that the rich save more of their income than the poor. It might be expected to come from what we know we have seen: very substantial reserve accumulation in developing countries. And from some developing countries, notably China in the past nine months, a very substantial capital flight. Indeed, the capital flight from China over the past nine months has been, depending on how one measures it, about three times as large as all the capital flight from all the emerging market crises of the 1990s. Longer life expectancy, more resistance to debt, more uncertainty, household deleveraging, and paying back debt are forms of saving.

What about the investment propensity? The labor force of the industrialized world is not going to grow over the next 20 years. That has implications for the demand for new equipment to equip workers, the demand for new housing to house them, and the need for new business structures to give them a roof over their heads as they work. Think about the de-massification of the economy. I was speaking with somebody in real estate not long ago who said that 15 years ago a good law firm would require 1300 square feet per lawyer. But today at least some law firms are trying to allocate less than 600 square feet per lawyer. Technology has lessened the demand for space-consuming filing cabinets, paralegals, and assistants. Offices can also be smaller since people are likely to spend more time with their laptops working at home. All of that means downward pressure on physical investment. Other examples include e-commerce and the demand for malls, Air B\&B and the demand for hotels. Not to mention Uber and the driverless car that will come and alter the demand for and number of automobiles.

People have tried to measure this at least since Alan Greenspan in the 1990s and have found that the total number of pounds of stuff per dollar of GDP is in a secular downward trend. And since a lot of that stuff is capital that means less investment. Capital goods are 


\section{Figure 14}

\section{Why Might Equilibrium Real Rates Have Fallen?}

\section{Increased Savings}

1. Changes in distribution of income and profits share

2. Reserve accumulation or capital flight

3. Increasing deleveraging and retirement preparation

\section{Decreases in Investment Propensity}

1. Declining growth rate of population and/or technology

2. Demassification of the economy

3. Fall in price of capital goods

\section{Other Factors}

1. Interaction between inflation and after-tax real rates

2. Increased frictions in intermediation

3. Increased global safe asset demand

getting cheaper, relative to other goods-most obviously anything to do with information technology. And that means one dollar of saving buys a lot more capital than it used to. That reduces the demand for capital as well. There are other factors, including the fact that financial intermediation works less efficiently because people are more nervous because of what happened and because of regulation. These forces push interest rates down. All of this taken together makes it highly plausible that we have seen a very substantial and structural increase in saving and decrease in investment resulting in low rates, resulting in a tendency toward economic sluggishness.

In important respects this is the deep cause of the financial crisis. After all, during the 2003-07 period the economy did fine overall. It did not overheat, it did not perform spectacularly. It did fine. And yet what did it take to propel it to "fine"? It took what we now see as a vast erosion of credit standards and the mother of all bubbles in the housing market. Without those things, growth would have been inadequate in 2003-07. Or, to put the point differently, if the economy had been overheating, the Fed would have provided the interest rate increases that would have cut off the housing bubble much sooner. And so this structural tendency toward too much saving relative to investment is both the reason why we have sluggishness now and the reason why the periods of robust growth increasingly prove not to be sustainable. Indeed, here is a potted version of recent American economic history. We have had a very slow recovery. Before that we had the financial crisis. Before that we had growth on what we now know to have been an unsustainable financial foundation. Before that we had the recession and slow recovery from 2001 to 2003 . And before that we had rapid growth propelled by the Internet bubble. And so if one asks when was the last time that the American economy grew at a rapid rate with clearly strong financial underpinnings, one would have to go back 


\section{Figure 15}

\section{No Obvious Reason for Equilibrium Rate to Rise}

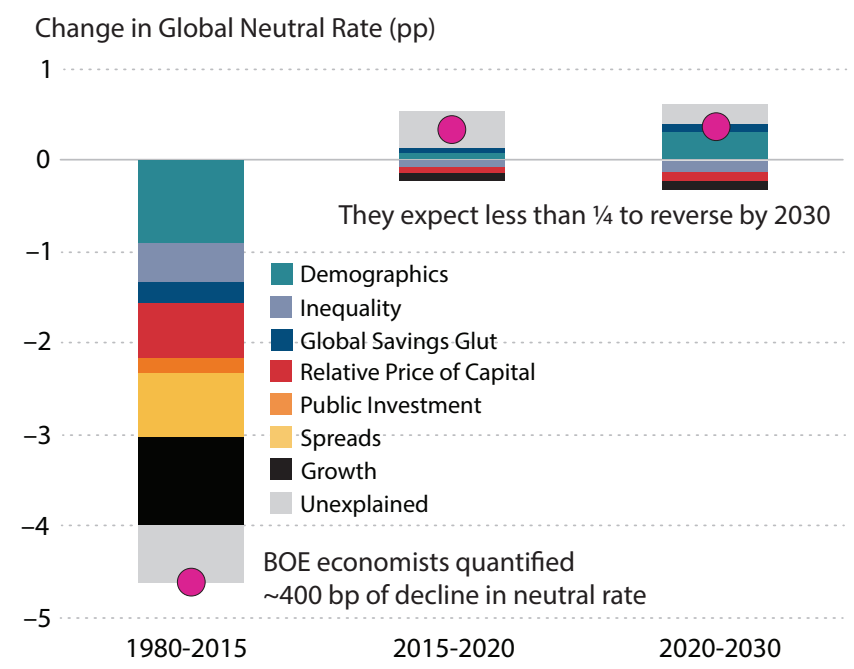

SOURCE: Bank of England Staff Working Paper \#571, "Secular drivers of the global real interest rate" by Lukasz Rachel and Thomas Smith; http://www.bankofengland.co.uk/research/Pages/workingpapers/2015/swp571.aspx.

close to a generation ago to find that time. And the underlying reason is this excess of saving over investment.

Through most of this period the Federal Reserve has been inclined to say, "Well, the economy is held back by headwinds but the headwinds will recede as a recovery continues and then we will be in a position to normalize rates." That is the view that was behind all the overoptimism displayed in Figure 6 showing expected rate increases that never materialized. Belief in temporary headwinds was a very reasonable thing to think and say in 2009 or 2010 . There were all kinds of huge aftershocks and aftereffects of the financial crisis. It may well have been a reasonable thing to say in 2011 or even in 2012. But six or seven years after the financial crisis, it is hard to understand what the headwind is that one could reasonably expect to recede in the next two or three years. And I believe the answer is that it was not a temporary headwind; it was a permanent headwind driven by the factors that I have just described.

Lukasz Rachel and Thomas Smith at the Bank of England have attempted to quantify and forecast each one of these factors. Their judgment is that, on a global basis, real rates declined 400 basis points between 1980 and 2015 and that there is no particular reason to think that any significant part of that is coming back over the next 15 years (Figure 15).

I believe there is a good chance that judgment is correct. More saving, less investment, very low interest rates, problematic financial sustainability, and a tendency toward economic weakness. That is the secular stagnation hypothesis. Now, there are some alternatives to it (Figure 16). Some of them are kind of the same, and some of them I think are incomplete or inadequate as an explanation. 


\section{Figure 16}

\section{Differential Diagnosis}

Is weakness the result of deleveraging (Rogoff)?

- Does not account for long-term downtrend in rates

-What temporary headwinds still exist seven years into recovery?

\section{Is stagnation mostly on the supply side (Gordon)?}

- Lack of supply should lead to inflation, not deflation

- Likely correct that potential output and productivity growth is slow

Is this a global savings glut (Bernanke)?

- Emerging market surpluses have relatively declined

- A glut of savings and excess of savings over investment are very similar diagnosis

Is this a classic liquidity trap (Krugman)?

- Liquidity traps usually thought of as temporary

My Harvard colleague Ken Rogoff ${ }^{4}$ talks about a debt supercycle coming to an end and the need for deleveraging. A good story for 2011; not a very good story eight years after the crisis when financial conditions seem very much to have normalized. Also, not a story that explains why there has been a secular downward trend in real interest rates for between 20 and 30 years and that the pre-crisis trend tracks the current level of real interest rates. Bob Gordon suggests, importantly, that there is a great deal of structural weakness on the supply side ${ }^{5}-$ that whatever happens with demand, the economy's potential is rising less rapidly than it once did. And there is powerful evidence for that. The fact that GDP growth has been very weak but that unemployment is really quite low suggests that something very bad has happened to productivity. And that may well have to do with the various factors that Gordon described.

However, economists have a classic test for telling whether something is a supply-side phenomenon or a demand-side phenomenon. If the price of apples goes up and one wants to know whether it is because there is a shortage of apples or because apples have come into fashion, they should look at what happens to the quantity of apples. If the price of apples has gone up and there are a lot more apples being sold, then it is because there was more demand. If the price of apples goes up and the quantity of apples goes down, there was likely a problem at the orchards. What has happened recently? There have been steadily declining rates of underlying inflation in the industrial world. And long-term inflation expectations, despite the recovery, are very low by historical standards. So, yes, there are supply issues; but I think it would be a mistake to explain everything in terms of supply issues. The last time there were major supply issues was in the 1970s, and inflation today does not resemble inflation then.

Former Fed Chairman Ben Bernanke has suggested that low interest rates have been caused by a savings glut. ${ }^{6}$ I do not really want to argue with that. A savings glut is, after all, a lot like an excess of saving over investment, which is what I have posited. Bernanke sees the 
Table 2

\section{Current Forecasts Imply 35 Percent Chance of Recession Within Two Years}

\begin{tabular}{ccc} 
& 2016 & $\mathbf{2 0 1 7}$ \\
\hline Fed forecast & 2.20 & 2.15 \\
- Recessionary growth & 0.40 & 0.40 \\
Recessionary forecast error & 1.80 & 1.75 \\
\% RMSE of GDP forecasts & 1.80 & 2.10 \\
& 1.00 & 0.83 \\
Percent chance recession & 16 & 20
\end{tabular}

SOURCE: Federal Reserve Summary of Economic Projections; Federal Reserve Updated Forecast Errors.

\section{Table 3}

\section{Always a Decent Chance of Recession Intermediate Term}

\begin{tabular}{lccc} 
& \multicolumn{2}{c}{$\begin{array}{c}\text { Three+ year-old expansions } \\
\text { Percent of time recession within }\end{array}$} \\
\hline 2 Years & 3 Years & 5 Years \\
\hline Japan & $30 \%$ & $40 \%$ & $54 \%$ \\
Germany & $53 \%$ & $74 \%$ & $98 \%$ \\
U.K. & $28 \%$ & $40 \%$ & $63 \%$ \\
U.S. & $43 \%$ & $63 \%$ & $88 \%$
\end{tabular}

SOURCE: NBER; Economic Cycle Research Institute.

problem very much in terms of excess saving in developing countries. I look at the length of the trend, the variety of other factors that we have seen, and conclude that the problem is likely global and more permanent in nature.

Finally, Paul Krugman and others talk about the liquidity trap. Again, the liquidity trap is closely related to the difficulty in lowering interest rates enough to balance saving and investment that I have been talking about. The liquidity trap is usually, and in all of Krugman's formal modeling, treated as a temporary phenomenon. And it is the essence of the argument that this excess of saving over investment may be a phenomenon for the next era, not simply a temporary and cyclical phenomenon.

Here is why this is a critical problem that should be a focus of concern for policymakers in the United States. I do not know when the next recession is going to come. If one simply takes the prevailing Fed forecast and assumes the historical level of forecast accuracy, one would conclude recession odds of about one in six this year and about one in three over the next two years. (See Table 2.)

But another way to ask the question is to just ask what are the odds, if an expansion has been going for three years, that it will end sometime in the next two years? And here is the answer to that question in Table 3. One can interpret the data many ways, but I think it is hard to escape the conclusion that the odds are better than 50 percent that within three years the U.S. economy will have gone into recession.

Figure 17 shows why the possibility of recession is so concerning. It lists the decline in the real federal funds rate in the last nine business cycles. Both real and nominal short rate declines have averaged around 5 percentage points. Now, given what I have been arguing and the market is saying about future interest rates, it is highly unlikely that when the next recession comes there will be nearly enough room for the standard monetary policy response. The strategy for the past 40 years has been to respond to recessions with monetary easing. That monetary easing has typically been about 5 percentage points. And a best guess of the market of where interest rates will be when the next recession comes is that they will be at 2 percent. 
Figure 17

\section{Large Rate Cuts Are Often Necessary}

\begin{tabular}{lccc} 
& \multicolumn{3}{c}{ Real funds rate easings } \\
\cline { 2 - 4 } & Start & Final & Easing \\
\hline May 1960 & 1.9 & -0.1 & 2.0 \\
August 1966 & 3.1 & 0.7 & 2.3 \\
November 1970 & 4.5 & -0.9 & 5.4 \\
November 1974 & 6.4 & -1.6 & 8.0 \\
\hline May 1981 & 8.7 & -0.1 & 8.8 \\
September 1984 & 7.6 & 3.4 & 4.2 \\
November 1990 & 5.5 & 0.1 & 5.4 \\
\hline December 2000 & 4.8 & -0.4 & 5.2 \\
August 2007 & 3.3 & -1.1 & 4.4 \\
\hline
\end{tabular}

\section{Figure 18}

Monetary Policy Options

$\cdot$ Raise inflation target
$\cdot$ Forward guidance
$\cdot$ Broader QE
$\cdot$ Negative rates

SOURCE: Bloomberg; Core PCE Deflator from Bureau of Economic Analysis.

And so even if the next recession is typical and no worse, policymakers will either have to rely very substantially on unconventional monetary policy or something else.

Now, what are the monetary policy options that one can talk about? (See Figure 18.) The Fed has expressed confidence in its ability to use so-called unconventional policy. Incidentally, when you have responsibility for something and you are in government, it is a good idea to look like you have the problem under control even if you are not altogether certain that you do. So I do not fault the rhetoric of the Fed. But I do not think it is remotely realistic to think that there is anything like the equivalent of 300 basis points in unconventional monetary policy that is likely to be available when the next recession comes.

What are the tools that people talk about? Principally there are four. There is an argument that the Fed should raise its inflation target. That will be an interesting and important issue at some point, but it is like discussing whether I should lose 40 pounds or lose 60 pounds-a much more interesting issue after I have lost the first 20. And when inflation is consistently below 2 percent, discussing whether optimal is 3 or 4 or 5 percent seems a tad jejune.

There is the idea of forward guidance. This is the suggestion that the Fed can promise that it is going to keep rates low in the future and that will make longer-term rates low and will make everybody optimistic and will make them spend. Here is the problem: People already do not think the Fed's going to raise rates very much. There is not much more to promise than what has already been priced-in. People are already anticipating that rates are not going much above 2 percent.

There is broader quantitative easing. Now, I think quantitative easing was very effective at the beginning when there was substantial illiquidity in many fixed-income markets and 
when there were large credit spreads and steep term premia. When there are not steep term premia and when there are not large credit spreads, what rate is it that you are actually going to reduce substantially? What is the quantitative easing program that, starting with the 10 -year Treasury rate of 1.73 percent, is going to do anything like what a normal 3- or 5-percentagepoint reduction in interest rates will accomplish?

And finally, there is the idea of a venture into negative rates, which it seems to me is a quite uncertain experiment. Andrew Haldane at the Bank of England has made a fairly thorough study of this ${ }^{7}$ : There is interest rate data going back to Babylonian times, and there is no historical experience with negative rates. But in a world where you can put $\$ 20$ bills in a suitcase or $\$ 100$ bills in a suitcase, maybe interest rates can be -30 basis points or -60 basis points. Whatever the true minimum lower bound is, it is not all that big relative to what is necessary the next time a recession comes.

So there is a real question as to how effective unconventional monetary policy can be. But even if it could be effective, there are two other major problems with unconventional monetary policy. The first is what I would call the pull forward problem. The pull forward problem is the way monetary policy works by pulling spending forward. When the interest rate is lower, you buy a new car sooner than you otherwise would. When the interest rate is lower, you invest a lot in order to adjust your capital stock to a higher level because the interest rate is lower.

So if you have a temporary demand shortfall, a reduction in interest rates is terrific because it pulls forward demand to the moment where you have the shortfall. But if you have a permanent demand shortfall, at some point that pull forward catches up with you. At some point, yes, we increased demand in 2015; but the way we did it was by pulling demand from 2016 into 2015. And so unless you are going to have ever easier monetary policy at some point, the treadmill catches up with you. And then there is this: What is the consequence of the spending being generated with these unconventional hyper-liquidity measures? They are surely increasing the risk of making the mistakes of 2005-07. There are surely questions about the quality of the investment that people are not willing to make with a 1.75 percent 10 -year rate that they would be willing to make with a 1.25 percent rate.

My conclusion is not that the Federal Reserve has been wrong to try to respond to slack deflationary pressure in excess of saving over investment by letting interest rates and letting financial conditions adopt. My conclusion, though, is that the process has surely run into very severe diminishing returns and cannot be relied on the next time a recession comes. What is the implication of that? I would suggest two. A first implication is that surely it is very important to avoid the next recession coming anytime soon. That one should be prepared to take risks that one would not take in normal times to avoid recession. But the possible risks of recession and entrenched inflation expectations below 2 percent vastly exceed, in terms of their consequences, a hypothetical situation in which inflation rose to 2.3 or 2.7 percent. And that awareness needs to be present in the setting of monetary policy.

Second, normalization is the wrong objective in abnormal times. Normalization relative to historical experience is not appropriate in conditions where the natural, neutral, normal interest rate is very different from what it has been historically. More profoundly, traditional 
economics has assumed that changes in demand can naturally be offset by the workings of monetary policy. So in the conventional analysis of a policy area, changes in demand are abstracted away. But in a world where monetary policy is much more limited in its impact, the demand aspects of all other policies should be considered because they will not naturally be sterilized by the actions of the Federal Reserve. In that regard, I believe there should be a radical rethinking of the role of fiscal policy in economic stabilization. That with monetary policy able to do much less, fiscal policy will need to do much more. This rethinking of fiscal policy should reflect the fact that the sustainability of debt depends crucially on a comparison of interest rates and growth rates; and when interest rates are chronically and systemically low, debt burdens that would otherwise become imprudent become much more prudent, particularly in the context of getting an economy to grow.

And I will conclude by observing that at a moment when money has never been cheaper, a moment when materials cost are near record lows, a moment when those with the capacity to do construction work are still out of work in disproportionate numbers, it is difficult to imagine a better moment to stop paint chipping off school buildings or to fix LaGuardia Airport. And the United States right now has the lowest infrastructure investment rate that it has had since the Second World War. If you adjust for depreciation and round to the nearest integer, that investment rate is zero. And that seems to me manifestly inappropriate. And the only thing that is more wrong than the current low infrastructure investment rate is the absence of any systematic planning to rapidly build up and launch infrastructure when the next recession comes.

Policymakers need to adapt to a world that is very different. A world where the problems are as much of deflationary risks as of inflationary risks, of insufficient demand as of inadequate supply. A world of limits on the power of monetary policy. A world where fiscal policy matters, whether one has my kind of views of fiscal policy directed at public investment or other views of fiscal policy directed at stimulating private investment. This is not a matter of political ideology, but it is a matter of economic reality. A moment of very different economic conditions will require very different economic policy responses. And that is something both those charged with monetary policy responsibility and those who create the political frameworks in which monetary policy operates need to keep very much in mind in this era of secular stagnation. 


\section{Summers}

\section{NOTES}

1 This paper is adapted from a speech that included the following introduction: "Before I get into the substance of what I want to say, let me salute the St. Louis Fed. I was not a fan of hard-core monetarism. I think neo-Fisherian economics has an 80 to 90 percent chance of being mostly a confusion. But I think it is hugely important to our processes that there be experienced practical people exploring and pushing doctrines that are counterintuitive to the conventional wisdom. And so I salute the St. Louis Fed, which I think actually has stood out within the Federal Reserve System for nerve and verve in attempting to take on a role of intellectual leadership. And I think it is very, very important. And I have paid as much or more attention-even while disagreeing with some of it - to the research that has come out of the St. Louis Fed as I have to the research that has come out of any of the other 11 regional Reserve Banks. And so I salute Jim Bullard on his leadership, and I salute his predecessor, Bill Poole, and predecessors going farther back—as well as those who succeeded Homer Jones in the research department. Believe me, you are making a very important contribution to our national life."

2 "Secular" refers to the permanence of the stagnation.

3 https://research.stlouisfed.org/fred2/data/M0892AUSM156SNBR.txt.

4 http://voxeu.org/article/debt-supercycle-not-secular-stagnation.

5 http://piketty.pse.ens.fr/files/Gordon2015.pdf.

6 http://www.brookings.edu/blogs/ben-bernanke/posts/2015/03/31-why-interest-rates-low-secular-stagnation.

7 http://www.bankofengland.co.uk/publications/Documents/speeches/2015/speech828.pdf. 